\title{
Ion Channels and Transporters in Muscle Cell Differentiation
}

\author{
Lingye Chen ${ }^{1,2}\left(\mathbb{D}\right.$, Fatemeh Hassani Nia ${ }^{3}(\mathbb{D})$ and Tobias Stauber ${ }^{1,3, *}$ (D) \\ 1 Institute for Chemistry and Biochemistry, Freie Universität Berlin, 14195 Berlin, Germany; \\ lingyechen@zedat.fu-berlin.de \\ 2 Zhongshan School of Medicine, Sun Yat-Sen University, Guangzhou 510080, China \\ 3 Institute for Molecular Medicine, MSH Medical School Hamburg, 20457 Hamburg, Germany; \\ fatemeh.hassani-nia@medicalschool-hamburg.de \\ * Correspondence: tobias.stauber@medicalschool-hamburg.de; Tel.: +49-(40)-361-2264-3202
}

Citation: Chen, L.; Hassani Nia, F.; Stauber, T. Ion Channels and Transporters in Muscle Cell Differentiation. Int. J. Mol. Sci. 2021, 22, 13615. https://doi.org/10.3390/ ijms222413615

Academic Editor: Carlo Zancanaro

Received: 15 November 2021

Accepted: 14 December 2021

Published: 19 December 2021

Publisher's Note: MDPI stays neutral with regard to jurisdictional claims in published maps and institutional affiliations.

Copyright: (c) 2021 by the authors. Licensee MDPI, Basel, Switzerland. This article is an open access article distributed under the terms and conditions of the Creative Commons Attribution (CC BY) license (https:/ / creativecommons.org/licenses/by/ $4.0 /)$.

\begin{abstract}
Investigations on ion channels in muscle tissues have mainly focused on physiological muscle function and related disorders, but emerging evidence supports a critical role of ion channels and transporters in developmental processes, such as controlling the myogenic commitment of stem cells. In this review, we provide an overview of ion channels and transporters that influence skeletal muscle myoblast differentiation, cardiac differentiation from pluripotent stem cells, as well as vascular smooth muscle cell differentiation. We highlight examples of model organisms or patients with mutations in ion channels. Furthermore, a potential underlying molecular mechanism involving hyperpolarization of the resting membrane potential and a series of calcium signaling is discussed.
\end{abstract}

Keywords: bioelectricity; calcium signaling; cardiac differentiation; membrane potential; myoblast differentiation; stem cells; vascular remodeling

\section{Introduction}

Vertebrates possess three types of muscle tissue classified by morphology, function, and distribution: skeletal, cardiac, and smooth muscle. The movement of living organisms and the functioning of various visceral organs rely on muscle contraction and relaxation. These processes are controlled by endogenous bioelectric signaling mediated by ion channels and transporters. The loss or dysfunction of such transport proteins usually leads to serious diseases [1-4]. For example, mutations that disrupt the voltage-gated chloride channel ClC-1 [5-7] and the voltage-gated sodium channel $\mathrm{Na}_{\mathrm{v}} 1.4$ [8,9] result in myotonia congenita and paramyotonia congenita, respectively. Ion channels and their pathogenic roles have been extensively studied in mature, excitable muscle cells [10-13]. Moreover, there is increasing evidence that ion channels also play crucial roles in muscle development. In this review, we focus on these roles of ion channels and transporters. We summarize the molecular mechanisms by which ion channels or transporters regulate the differentiation of non-excitable stem or progenitor cells during myogenesis. Additionally, we emphasize the fundamental role of endogenous bioelectrical signals in developmental processes.

Similar to muscle cells, every living cell possesses a transmembrane potential $\left(V_{\mathrm{m}}\right)$ across the plasma membrane due to the uneven distribution of ions that is established or affected by various ion pumps, transporters, and channels. The range of resting membrane potentials varies between cell types. Stem cells and tumor cells tend to have a more positive, depolarized membrane potential, while terminally differentiated cells usually possess a much more negative, hyperpolarized resting potential [14-17]. For example, embryonic stem cells and skeletal muscle cells have resting membrane potentials of approximately $-10 \mathrm{mV}$ and $-90 \mathrm{mV}$, respectively $[14,16] . \mathrm{Ca}^{2+}$ is one of the most important second messengers in vertebrate cells. Numerous physiological and pathophysiological processes are closely related to $\mathrm{Ca}^{2+}$ signaling. In general, the cytoplasmic free $\mathrm{Ca}^{2+}$ concentration is much lower than that of the extracellular environment. An elevated intracellular $\mathrm{Ca}^{2+}$ concentration can result from $\mathrm{Ca}^{2+}$ influx through specific $\mathrm{Ca}^{2+}$ channels in the plasma 
membrane (voltage-gated, ligand-gated, or store-operated calcium channels) or by the release of $\mathrm{Ca}^{2+}$ from intracellular calcium stores such as the endoplasmic reticulum, lysosomes, or mitochondria.

\section{Ion Channels in Skeletal Myogenesis}

\subsection{Membrane Hyperpolarization}

Skeletal muscle formation occurs during the entire lifespan of vertebrates, including embryonic development, postnatal growth, and damage repair in adults $[18,19]$. Myogenesis from myogenic precursor cells (myoblasts) generally begins with cell cycle withdrawal, followed by the expression of muscle-specific transcription factor myogenin and the subsequent fusion of multiple cells into multinucleated myotubes (Figure 1) [20,21]. Hyperpolarization of the membrane potential is a prerequisite for skeletal muscle myoblast differentiation. This hyperpolarization can result from an efflux of cations, most likely $\mathrm{K}^{+}$ according to the given intracellular and extracellular concentrations, or theoretically by an influx of anions. Primary muscle progenitor cells derived from single satellite cells maintain their stem cell identity rather than undergo myogenic commitment when hyperpolarization is impaired by high external $\mathrm{K}^{+}$or the $\mathrm{Na}^{+}, \mathrm{K}^{+}$-ATPase inhibitor ouabain [22-24]. More specifically, upon induction of the myogenic differentiation of human myoblasts, the activation of an ether-à-go-go (EAG) $\mathrm{K}^{+}$channel has been shown to rapidly hyperpolarize myoblasts from approximately $-8 \mathrm{mV}$ to approximately $-32 \mathrm{mV}$ [25-27]. This is followed by a further drop in the resting membrane potential to approximately $-74 \mathrm{mV}$ due to the activation of the inward-rectifying $\mathrm{K}^{+}$channel Kir2.1 [27-29]. The human EAG $\mathrm{K}^{+}$current density was reported to be low in proliferating myoblasts, to increase in fusion-competent myoblasts, and to decline again in myotubes [27]. By contrast, the Kir2.1 current has been found to be expressed in 40-50\% of differentiating myoblasts and in all myotubes [22,27]. Notably, the activation of plasma membrane-localized Kir2.1 channels by dephosphorylation of Tyr242 is considered one of the earliest detectable events during myoblast differentiation [28]. It occurs within the first $6 \mathrm{~h}$ of differentiation, several hours before the expression of the two myogenic transcription factors myogenin and myocyte enhancer factor 2 (MEF2) [22,30].

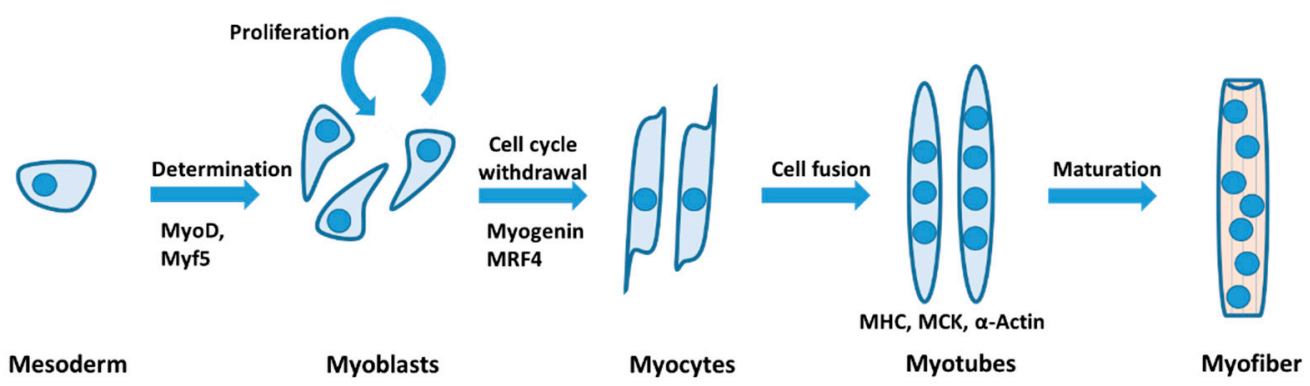

Figure 1. Myogenic differentiation. The scheme shows the differentiation of skeletal muscle from the mesoderm that is determined in the skeletal muscle lineage after MyoD and Myf5 expression. Myoblasts proliferate until they withdraw from the cell cycle and differentiate into myocytes, which involves myogenin and MRF4. Myocytes fuse to form myotubes that express skeletal muscle proteins myosin heavy chain (MHC), muscle creatine kinase (MCK), and $\alpha$-actin. Adapted from [31].

In addition to these contributors of hyperpolarization, several types of ion channels, including ether-à-go-go-related gene (ERG) $\mathrm{K}^{+}$channels [29], store-operated $\mathrm{Ca}^{2+}$ entry (SOCE) channels [32], and volume-regulated anion channels (VRACs) [33,34], have been shown to affect the resting membrane potential of fusion-competent myoblasts. Inhibition of the human ERG $\mathrm{K}^{+}$channel activity depolarized myoblasts by approximately $10 \mathrm{mV}$ [29], whereas knockdown of the stromal interaction molecule 1 (STIM1) or Orai1, reducing SOCE, impaired hyperpolarization and consequently inhibited myoblast differentiation [32]. Furthermore, it has been reported that, by activating the intermediateconductance $\mathrm{Ca}^{2+}$-activated $\mathrm{K}^{+}$channel $\left(\mathrm{IK}_{\mathrm{Ca}}\right)$, extracellular 5'-guanosine-triphosphate 
(GTP) hyperpolarizes $\mathrm{C} 2 \mathrm{C} 12$ cells from a mean value of $-15 \mathrm{mV}$ to approximately $-75 \mathrm{mV}$ and increases myosin heavy chain (MHC) expression [35-37]. VRAC is a plasma membrane channel formed by heteromers of leucine-rich repeat containing family 8 (LRRC8) members that mediates the flux of $\mathrm{Cl}^{-}$and organic osmolytes in a variety of physiological processes [38-42]. Using an optical activity sensor [43], VRAC was shown to be transiently activated during the early stage of $\mathrm{C} 2 \mathrm{C} 12$ (a mouse skeletal muscle myoblast cell line that expresses all five LRRC8 family members [44]) differentiation, which was also accompanied by a reduction in intracellular chloride [34]. While VRAC is not required for C2C12 proliferation [45], knockdown of the essential LRRC8A subunit [46,47] or pharmacological inhibition of its activity impaired the hyperpolarization and subsequent fusion of $\mathrm{C} 2 \mathrm{C} 12$ myoblasts [33]. However, a VRAC-mediated efflux of $\mathrm{Cl}^{-}$per se, which is evidenced by the increased cytosolic $\mathrm{Cl}^{-}$upon VRAC inhibition, cannot contribute to the hyperpolarization. An explanation may be that VRAC affects other channels such as Kir2.1. VRAC was also proposed to be involved in myotube differentiation by regulating signaling independent of its ion transport activity [48].

The analysis of human patients and animal models provide in vivo evidence for the importance of ion channel function in the development of skeletal muscle. Patients with mutations in the KCNJ2 gene, which encodes the Kir2.1 potassium channel, exhibit severe craniofacial and limb defects, such as cleft palate and brachydactyly (shortened digits) [49-51]. Kir2.1 knockout mice also display a cleft palate and patterning defects in their skeletal digits [52,53]. Mice with global or skeletal muscle-specific deletions of STIM1 [54-56] and Orai1 [57-59] exhibit a drastically reduced muscle mass and much smaller body size compared with their wild-type littermates. Furthermore, mice lacking the essential LRRC8A subunit of the VRAC exhibited severe growth retardation, high prenatal and postnatal lethality, and various organ abnormalities, including thin skeletal muscle bundles [60]. However, targeted deletion of LRRC8A in skeletal muscle resulted in significantly smaller myofibers without affecting total muscle mass [48].

\section{2. $\mathrm{Ca}^{2+}$ Signaling}

An increase in the free cytoplasmic $\mathrm{Ca}^{2+}$ concentration is required for the expression of myogenic transcription factors and the formation of normal-sized myotubes [23,61-64]. The hyperpolarization of human myoblasts induced by the sequential activation of EAG and Kir2.1 has been shown to trigger a small but sustained influx of $\mathrm{Ca}^{2+}$ through $\alpha 1 \mathrm{H}$ T-type voltage-gated $\mathrm{Ca}^{2+}$ channels (VGCCs), sufficient to cause a significant increase in the resting intracellular $\mathrm{Ca}^{2+}$ concentration $[29,62]$. This cytosolic $\mathrm{Ca}^{2+}$ signal activates the calcineurin/NFAT pathway, thereby inducing the expression of myogenin and MEF2 (Figure 2) [23]. Another $\mathrm{Ca}^{2+}$-dependent pathway involving the $\mathrm{Ca}^{2+} /$ calmodulindependent kinase (CaMK), is required for myogenin expression [65] but does not link to Kir2.1-induced hyperpolarization [23]. Interestingly, a $10 \mathrm{mV}$ depolarization of the resting potential was observed to increase the T-type $\mathrm{Ca}^{2+}$ current and to raise the intracellular free $\mathrm{Ca}^{2+}$ concentration, thus triggering a ten-fold acceleration of human myoblast fusion [29]. However, the involvement of T-type VGCCs as a primary $\mathrm{Ca}^{2+}$ entry mechanism in myoblast differentiation seems to be species-dependent, as it was shown that L-type rather than T-type $\mathrm{Ca}^{2+}$ currents can regulate the expression of myogenin and MHC in murine C2C12 cells [66,67]. A link between L-type VGCCs and calcineurin activity has also been suggested [68]. 


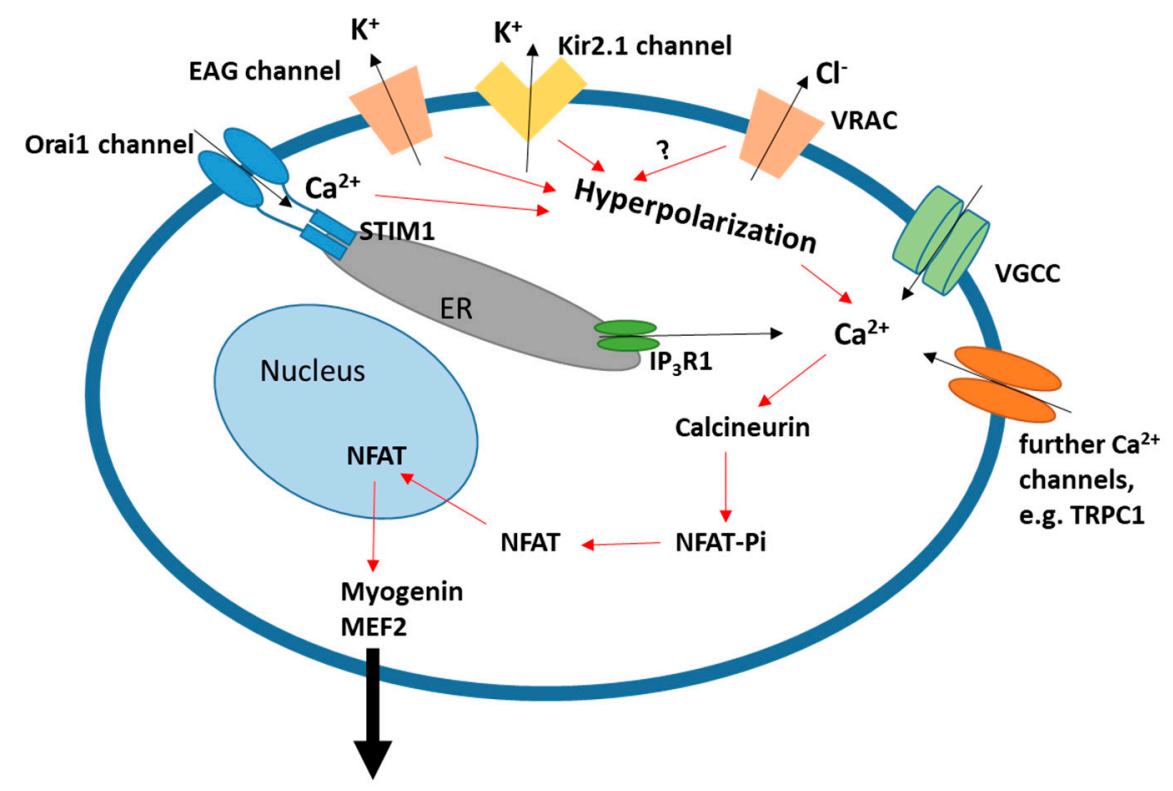

Myoblast differentiation

Figure 2. Membrane hyperpolarization and calcium signaling in myoblast differentiation. The sequential activity of EAG and Kir2.1 $\mathrm{K}^{+}$channels leads to membrane hyperpolarization, which in turn is required for $\mathrm{Ca}^{2+}$ signaling. $\mathrm{Ca}^{2+}$ release from the ER, which leads to activation of SOCE, can contribute to the $\mathrm{Ca}^{2+}$ signal. Activity of the $\mathrm{Cl}^{-}$channel VRAC contributes to hyperpolarization by an unknown mechanism. See the main text for details.

Intracellular $\mathrm{Ca}^{2+}$ can also be elevated during myoblast differentiation when $\mathrm{Ca}^{2+}$ is released from the endoplasmic reticulum (ER) through inositol 1,4,5 tris-phosphate receptors $\left(\mathrm{IP}_{3} \mathrm{Rs}\right)$, followed by $\mathrm{Ca}^{2+}$ entry through SOCE channels [69-73]. Knockdown of $\mathrm{IP}_{3} \mathrm{R} 1$ in human myoblasts impaired both endogenous spontaneous $\mathrm{Ca}^{2+}$ oscillations and SOCE, which in turn reduced the activity of two key enzymes of muscle differentiation: calcineurin and CaMKII [74]. By contrast, the overexpression of $\mathrm{IP}_{3} \mathrm{R} 1$ not only rescued normal differentiation in $\mathrm{IP}_{3} \mathrm{R} 1$-silenced myoblasts but also increased the percentage of MEF2-positive nuclei after one day of differentiation [74]. In zebrafish, it was shown that, in addition to the $\mathrm{IP}_{3}$ receptor, the $\mathrm{Ca}^{2+}$-dependent ryanodine receptor (RyR) also contributes to the cytosolic $\mathrm{Ca}^{2+}$ signal during myogenesis upon lysosomal $\mathrm{Ca}^{2+}$ release by two-pore channel type 2 (TPC2) activation [75,76]. Upon ER $\mathrm{Ca}^{2+}$ store depletion, the $\mathrm{Ca}^{2+}$ sensor STIM1 triggers $\mathrm{Ca}^{2+}$ influx through SOCE-mediating channels located at the ER-plasma membrane junction, thereby efficiently restoring the $\mathrm{ER} \mathrm{Ca}^{2+}$ content [77-79]. Here, two classes of channels are involved [80]: Orai channels [77,81] and transient receptor potential canonical channels (TRPCs) [82,83]. The important roles of STIM1 [32,54-56,84], Orai1 [32,57-59], TRPC1 [85-88], and TRPC4 $[89,90]$ during myogenesis in mouse and human have been established. Silencing any of them reduced SOCE and myoblast differentiation, whereas the forced expression of STIM1 with Orai1, TRPC,1 or TRPC4 in human myoblasts increased SOCE, accelerated myoblast fusion, and produced hypertrophic myotubes $[32,89]$. Furthermore, the $N$-methyl- $D$-aspartate (NMDA) receptor, a subtype of ionotropic glutamate receptors, was also shown to mediate $\mathrm{Ca}^{2+}$ influx and to promote $\mathrm{C} 2 \mathrm{C} 12$ myoblast fusion [91]. It is worth recalling that the graded $\mathrm{Ca}^{2+}$ signal involved in skeletal muscle formation depends on $\mathrm{Ca}^{2+}$ release from intracellular stores as well as $\mathrm{Ca}^{2+}$ influx from the extracellular space [29,69]. However, all of these $\mathrm{Ca}^{2+}$ signals are inhibited when the hyperpolarization process that increases the driving force for $\mathrm{Ca}^{2+}$ is blocked $[23,33,36,63]$. Notably, SOCE is involved in both hyperpolarization and subsequent $\mathrm{Ca}^{2+}$ signaling. Moreover, muscles from TRPC1 knockout mice display reduced fiber cross-sectional area and contain less myofibrillar proteins [86,92]. 


\subsection{Further Molecular Mechanisms}

The failure of myoblasts to exit the cell cycle leads to defective myotube formation $[20,93]$. It was reported that blocking the $\mathrm{Ca}^{2+}$ - and voltage-dependent $\mathrm{K}^{+}$channel KCa1.1 in human primary myoblasts increased the levels of cytosolic $\mathrm{Ca}^{2+}$ and activated NFkB, which resulted in enhanced cell proliferation and reduced fusion [94]. Interestingly, KCa1.1 expression in myotonic dystrophy type 1 (DM1) myoblasts was found to be significantly decreased [95], whereas introducing functional KCa1.1 $\alpha$-subunits into DM1 myoblasts reduced their proliferation to normal levels and rescued the expressions of MEF2 and myogenin [94]. While constitutive overexpression of the protein called chloride intracellular channel 5 (CLIC5) partly shifted C2C12 cells from G2/M phase to G0/G1 phase, resulting in decreased cell proliferation and increased expression levels of myogenin and MHC [96], a direct effect of altered ion transport remains to be shown because it is unlikely that CLICs function indeed as chloride channels [97]. The activation of $\mathrm{K}_{\mathrm{v}} 7$ channels reduced proliferation and stimulated differentiation of $\mathrm{C} 2 \mathrm{C} 12$ myoblasts [98]. In particular, it was reported that the endocannabinoid 2-arachidonoylglycerol inhibits skeletal muscle differentiation via cannabinoid type 1 receptor-mediated inhibition of $\mathrm{K}_{\mathrm{v}} 7.4$ channels [99]. Knockdown of $\mathrm{K}_{\mathrm{v}} 7.4$ reduced the expression levels of several differentiation markers, but overexpression of $\mathrm{K}_{\mathrm{v}} 7.4$ did not enhance myoblast differentiation [100].

Inhibition of mechanosensitive (or stretch-activated) cation channels by pharmacological blockers leads to impaired phenotypic maturation of $\mathrm{C} 2 \mathrm{C} 12$ myoblasts, including reduced expression of sarcomeric proteins and MHC and decreased creatine kinase activity [101,102], with contradicting findings on the inhibitory effect on myogenin expression. Several further ion transport proteins have been implicated in skeletal myogenesis, including TRPC3 [103], Pannexin1 and Pannexin3 [104], connexin43 [88,105,106], twopore domain potassium channels TASK2 and TREK1 [107], nicotinic acetylcholine receptors [63,108], transient receptor potential vanilloid 1 (TRPV1) [109,110], and $\mathrm{Na}^{+} / \mathrm{K}^{+} / 2 \mathrm{Cl}^{-}$ cotransporter 1 (NKCC1) [111]. However, the specific mechanistic roles of these proteins in myogenic differentiation have not yet been elucidated.

\section{Ion Channels and Transporters in Cardiac Differentiation}

The heart is the first inner organ to form and function in the embryo. After birth, unlike skeletal muscle, the division or generation of cardiac muscle cells only occurs as a very slow process [112-114]. Due to the controversy or limitations surrounding cardiac progenitor cells $[112,115,116]$, here, we focus on data describing cardiac differentiation of pluripotent stem cells (PSCs), such as embryonic stem cells (ESCs) and induced pluripotent stem cells (iPSCs). The differentiation of PSCs into cardiomyocytes is usually accomplished by the embryoid body method and is characterized by sequential expression of a series of genes: initial mesoderm and cardiomesoderm markers (brachyury $\mathrm{T}$ and mesoderm posterior protein 1 (MESP1)), followed by cardiac-specific transcription factors (NKX2.5, GATA4, and MEF2C), and finally cardiac-specific structural proteins (cardiac Troponin I (cTnI), MYH6, MYH7, and myosin light chain 2a (MLC2A)) (Figure 3) [112,115,117]. Interestingly, the activation of $\mathrm{Ca}^{2+}$-activated $\mathrm{K}^{+}$channels (SKCas) (mainly the intermediate-conductance SKCa SK4) induced hyperpolarization of the membrane potential in undifferentiated murine ESCs, thereby inducing cardiac differentiation [118]. This suggests that membrane hyperpolarization precedes the signaling cascades of mesoderm commitment and cardiomyocyte specification. Notably, it was proposed that SKCa activation induces efficient cardiac differentiation of ESCs by activating the Ras-Mek1/2-ERK1/2 signal transduction pathway [118]. A recent study showed that the $\mathrm{K}^{+}$channel ERG1 is involved in the cardiac differentiation of rat ESCs by interacting with integrin $\beta 1$ and thus activating the AKT pathway (Figure 4) [119]. 


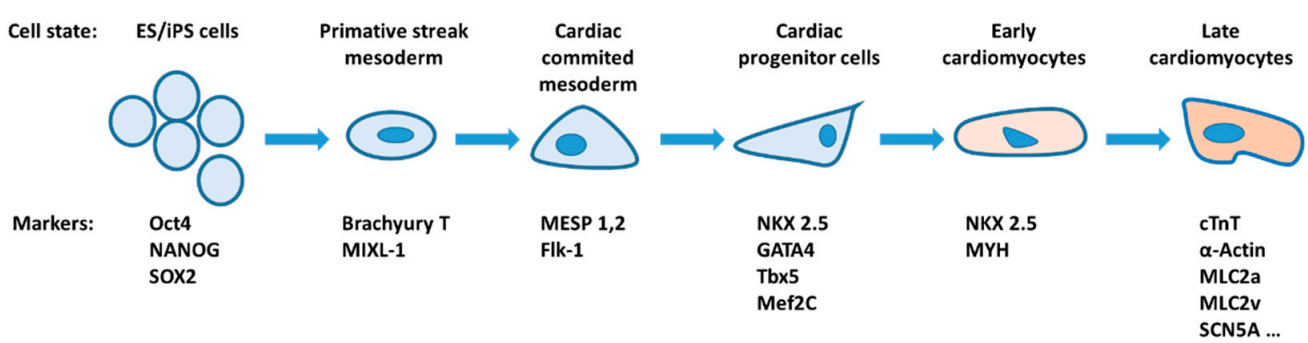

Figure 3. Cardiac differentiation. The scheme represents the different cell states during cardiac differentiation from pluripotent stem cells with the corresponding molecular markers. Adapted from [120].

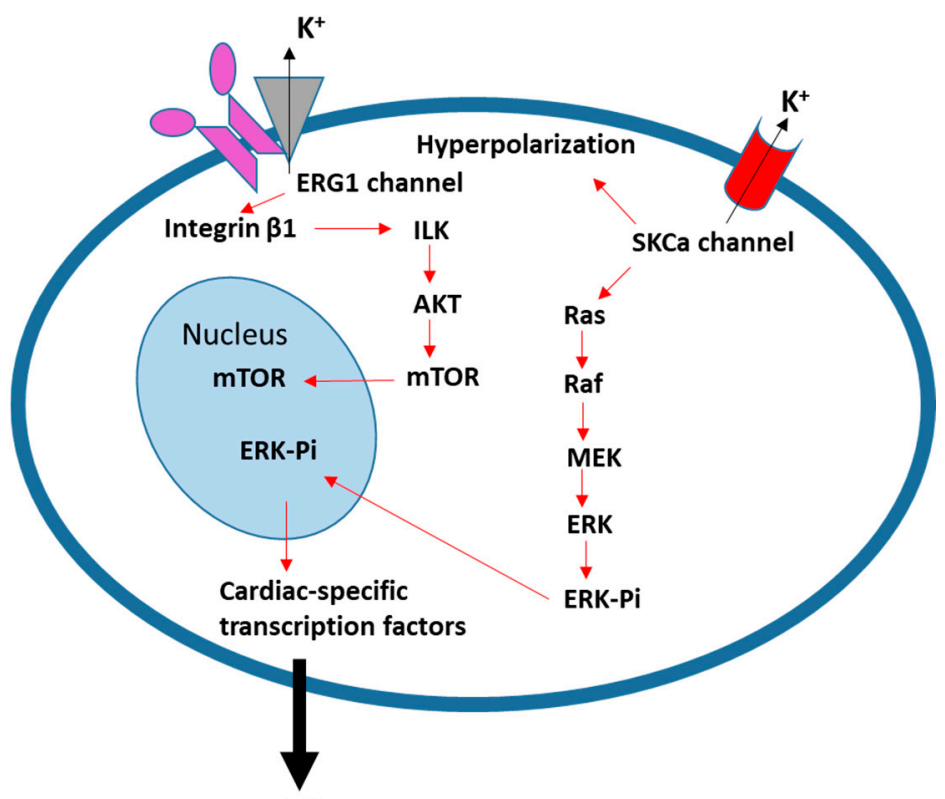

Cardiac differentiation

Figure 4. Membrane hyperpolarization and ion channel activation in cardiac differentiation. The activity of ERG1 and SKCa $\mathrm{K}^{+}$channels lead to membrane hyperpolarization and signaling to cardiac differentiation. See the main text for details.

The sources of intracellular $\mathrm{Ca}^{2+}$ signals vary with the differentiation stage of PSCderived cardiomyocytes and embryos maintained ex vivo [121-123]. In particular, the $\mathrm{Na}^{+} / \mathrm{Ca}^{2+}$ exchanger NCX1 is expressed during the earliest stages of heart development [123-125] and pharmacological blockade of NCX1 impacted on CaMKII signaling to downregulate the expression of key cardiac markers (Nkx2.5, Myh6, and Tnnt2 (encoding cTnT)), which led to impaired differentiation and failure of cardiac crescent formation [123]. The inhibition of L-type $\mathrm{Ca}^{2+}$ channels that are also expressed in the early stages of cardiac development resulted in the downregulation of Myh6 and Tnnt2 and a reduction in beating embryoid bodies [123]. In addition, the activity of the $\mathrm{Na}^{+} / \mathrm{H}^{+}$exchanger NHE1 was shown to promote cardiomyocyte differentiation; however, the mechanism has so far remained unknown [126]. In contrast with skelatal muscle differentiation, there is no clear data on a contribution of intracellular calcium stores, such as the ER, lysosomes, or mitochondria, in cardiac muscle differentiation.

A mutation that disrupts the ERG $\mathrm{K}^{+}$channel activity causes severe cardiac phenotypes in human patients, including QT prolongation, functional AV conduction disturbances, and polymorphic ventricular arrhythmias [127]. Similarly, another missense mutation in the human ERG, when introduced into the orthologous mouse gene in mouse ESCs, causes developmental cardiac defects in the right ventricle and its outflow tract. Homozygous mutant offspring died in utero by embryonic day 11.5 [128]. Mutations that 
result in reduced voltage-dependent channel inactivation of a specific L-type $\mathrm{Ca}^{2+}$ channel, $\mathrm{Ca}_{\mathrm{v}} 1.2$, cause defects in heart development in human patients. These defects include lethal arrhythmias and congenital heart disease $[129,130]$.

\section{Ion Channel Activity in Smooth Muscle Cell Differentiation}

Compared with skeletal muscle, there is only scarce information on the role of ion channels or transporters in vascular smooth muscle cell (VSMC) differentiation. VSMCs arise from multiple origins during embryonic development [131,132]. Although various in vitro models have been established to investigate the detailed mechanisms of deriving VSMCs from stem cells, it appears that origin-specific VSMCs possess individual regulatory mechanisms regarding the control of differentiation [133,134]. On the other hand, unlike cardiac and skeletal muscle cells, VSMCs do not terminally differentiate but maintain the ability to undergo phenotypic modulation in response to physiological and pathological stimuli, switching between a fully differentiated and contractile phenotype and a highly proliferative, migratory, and synthetic phenotype [135]. The limited progress made in defining VSMC differentiation [136-138] makes it more difficult to determine the role of ion channels or transporters in this process.

Many studies have presented confusing or apparently contradicting data on $\mathrm{Ca}^{2+}$ signaling, mostly by influx from the extracellular space [139-143]. Little is known about a potential role of intracellular $\mathrm{Ca}^{2+}$ stores in VSMC differentiation. While the lysosomal channels TRPML1 and TPC2 were shown to contribute to $\mathrm{Ca}^{2+}$ signaling in differentiated smooth muscle cells $[144,145]$, a role for lysosomal as well as mitochondrial $\mathrm{Ca}^{2+}$ in their differentiation is unknown. The relative contributions of plasma membrane and $\mathrm{ER} \mathrm{Ca}^{2+}$ channels in the plasma membrane alters when smooth muscle cells switch between a contractile and a proliferative phenotype $[146,147]$. However, this change in $\mathrm{Ca}^{2+}$ signaling does not seem to affect cell differentiation [148].

Nevertheless, it is beyond doubt that ion channels are critically involved in the development of vascular smooth muscle as well. One example is the ERG1 $\mathrm{K}^{+}$channel, in which deletion results in defects in the yolk sac and intraembryonic vasculature. Treatment with the specific ERG1 antagonist dofetilide, both in vivo and in vitro, recapitulates this vascular phenotype [149]. Interestingly, a recent study demonstrated the importance of plasma membrane hyperpolarization in VSMC differentiation [150]. First, the induction of contractile differentiation of primary VSMCs by transforming growth factor TGF- $\beta 1$ treatment caused hyperpolarization of the resting membrane potential. Second, TGF- $\beta 1$-stimulated VSMC differentiation in the mesenchymal stem cell line C3H10T1/2 was inhibited in a dose-dependent manner in the presence of additional extracellular $\mathrm{KCl}$. Furthermore, it was reported that TRPC6-mediated $\mathrm{Ca}^{2+}$ influx and depolarization suppressed VSMC differentiation by coordinately promoting the interaction of TRPC6 with lipid phosphatase and PTEN (phosphatase and tensin homolog) [150].

\section{Conclusions}

It is becoming increasingly clear that ion channels and transporters play conserved roles in developmental processes [151]. In contrast with transcriptional networks and signaling mechanisms, the emerging field of bioelectricity is a reservoir of new discoveries to be explored [15-17]. Changes in the resting membrane potential-as distinguished from transient membrane potential changes or oscillations during physiological processes-can be an instructive parameter in regulating cell fate decisions [152]. There are challenges to the investigation of the role for ion channels in cell differentiation, such as the fact that they can operate within a very narrow time window and that their regulation is not necessarily associated with changes in protein expression. The integration of various $\mathrm{Ca}^{2+}$ signals further adds to the complexity. Future research is required for identifying the intracellular or extracellular stimuli that control the activity of ion channels and transporters, and their downstream signaling. Elucidating the mechanisms by which ion channels and transporters promote muscle cell differentiation will lead to a better understanding of 
muscle development or disease and will provide insight for the development of therapeutic strategies relying on drugs or regenerative medicine.

Author Contributions: All authors contributed to the writing, and have read and agreed to the published version of the manuscript.

Funding: This research received no external funding. The publication of this article was funded by Freie Universität Berlin.

Conflicts of Interest: The authors declare no conflict of interest.

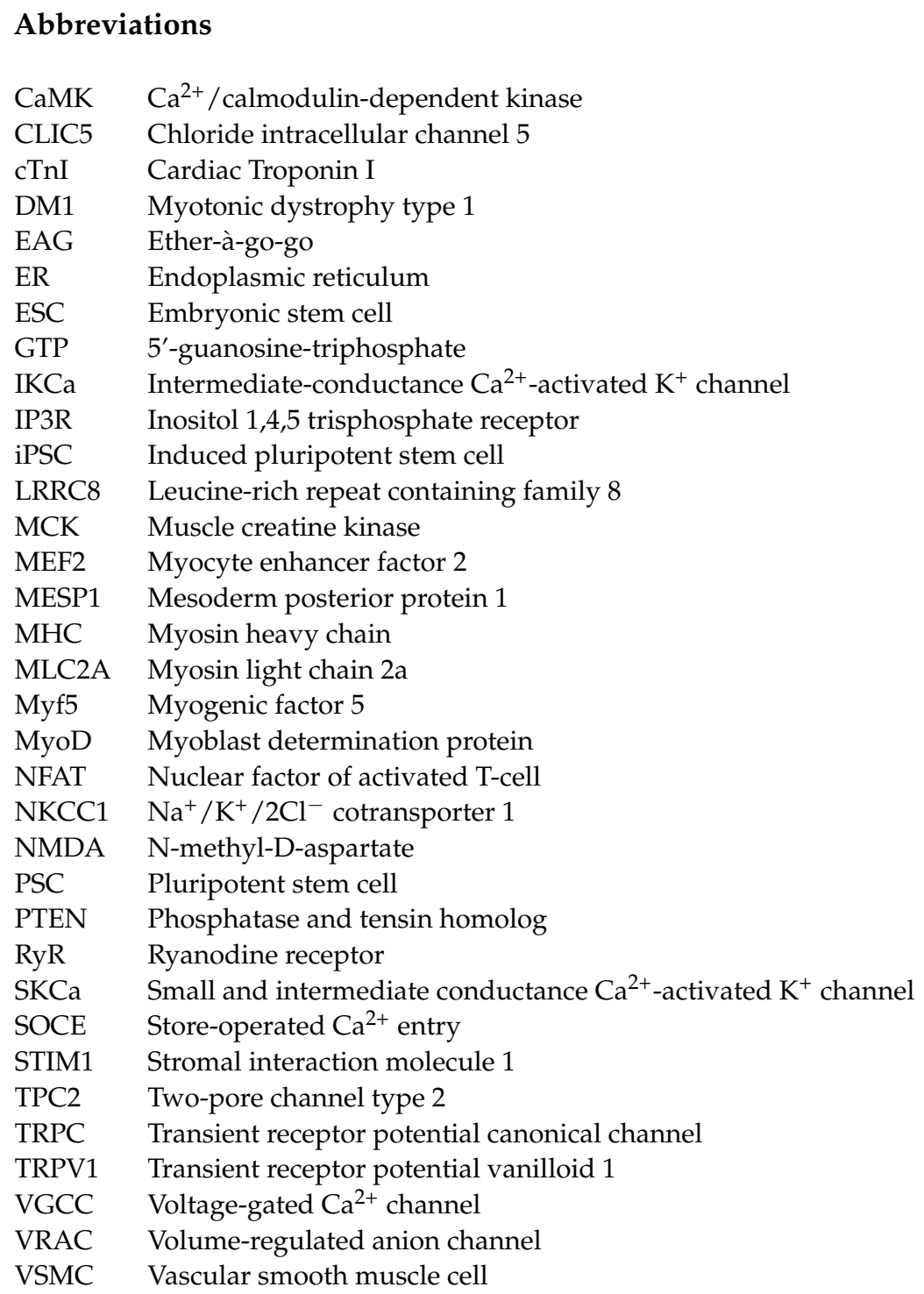

\section{References}

1. Camerino, D.C.; Tricarico, D.; Desaphy, J.-F. Ion channel pharmacology. Neurotherapeutics 2007, 4, 184-198. [CrossRef] [PubMed]

2. Planells-Cases, R.; Jentsch, T.J. Chloride channelopathies. Biochim. Biophys. Acta Mol. Basis Dis. 2009, 1792, 173-189. [CrossRef]

3. Enkvetchakul, D. Genetic Disorders of Ion Channels. Mo. Med. 2010, 107, 270-275. [PubMed]

4. Liu, Y.; Wang, K. Exploiting the Diversity of Ion Channels: Modulation of Ion Channels for Therapeutic Indications. In Concepts and Principles of Pharmacology; Springer: Berlin/Heidelberg, Germany, 2019; Volume 260, pp. 187-205. [CrossRef]

5. Koch, M.C.; Steinmeyer, K.; Lorenz, C.; Ricker, K.; Wolf, F.; Otto, M.; Zoll, B.; Lehmann-Horn, F.; Grzeschik, K.-H.; Jentsch, T.J. The Skeletal Muscle Chloride Channel in Dominant and Recessive Human Myotonia. Science 1992, 257, 797-800. [CrossRef] [PubMed]

6. Pedersen, T.H.; Riisager, A.; de Paoli, F.V.; Chen, T.-Y.; Nielsen, O.B. Role of physiological ClC-1 Cl- ion channel regulation for the excitability and function of working skeletal muscle. J. Gen. Physiol. 2016, 147, 291-308. [CrossRef] [PubMed] 
7. Jeng, C.-J.; Fu, S.-J.; You, C.-Y.; Peng, Y.-J.; Hsiao, C.-T.; Chen, T.-Y.; Tang, C.-Y. Defective Gating and Proteostasis of Human ClC-1 Chloride Channel: Molecular Pathophysiology of Myotonia Congenita. Front. Neurol. 2020, 11, 76. [CrossRef]

8. Cannon, S.C. Sodium Channelopathies of Skeletal Muscle. Mediat. Drugs Gastrointest. Motil. I 2017, 246, 309-330. [CrossRef]

9. Mantegazza, M.; Cestèle, S.; Catterall, W.A. Sodium channelopathies of skeletal muscle and brain. Physiol. Rev. 2021, 101, 1633-1689. [CrossRef]

10. Cannon, S. Channelopathies of Skeletal Muscle Excitability. Muscle 2012, 5, 1013-1022. [CrossRef]

11. Phillips, L.; Trivedi, J.R. Skeletal Muscle Channelopathies. Neurotherapeutics 2018, 15, 954-965. [CrossRef]

12. Kline, J.; Costantini, O. Inherited Cardiac Arrhythmias and Channelopathies. Med Clin. North Am. 2019, 103, 809-820. [CrossRef]

13. Wallace, E.; Howard, L.; Liu, M.; O’Brien, T.; Ward, D.; Shen, S.; Prendiville, T. Long QT Syndrome: Genetics and Future Perspective. Pediatr. Cardiol. 2019, 40, 1419-1430. [CrossRef]

14. Binggeli, R.; Weinstein, R.C. Membrane potentials and sodium channels: Hypotheses for growth regulation and cancer formation based on changes in sodium channels and gap junctions. J. Theor. Biol. 1986, 123, 377-401. [CrossRef]

15. Yang, M.; Brackenbury, W.J. Membrane potential and cancer progression. Front. Physiol. 2013, 4, 185. [CrossRef] [PubMed]

16. Levin, M.; Pezzulo, G.; Finkelstein, J.M. Endogenous Bioelectric Signaling Networks: Exploiting Voltage Gradients for Control of Growth and Form. Annu. Rev. Biomed. Eng. 2017, 19, 353-387. [CrossRef] [PubMed]

17. Levin, M. Molecular bioelectricity: How endogenous voltage potentials control cell behavior and instruct pattern regulation in vivo. Mol. Biol. Cell 2014, 25, 3835-3850. [CrossRef] [PubMed]

18. Bentzinger, C.F.; Wang, Y.X.; Rudnicki, M.A. Building Muscle: Molecular Regulation of Myogenesis. Cold Spring Harb. Perspect. Biol. 2012, 4, a008342. [CrossRef]

19. Chal, J.; Pourquié, O. Making muscle: Skeletal myogenesis in vivo and in vitro. Development 2017, 144, 2104-2122. [CrossRef] [PubMed]

20. Walsh, K.; Perlman, H. Cell cycle exit upon myogenic differentiation. Curr. Opin. Genet. Dev. 1997, 7, 597-602. [CrossRef]

21. Sampath, S.C.; Sampath, S.C.; Millay, D.P. Myoblast fusion confusion: The resolution begins. Skeletal Muscle 2018, 8, 3. [CrossRef]

22. Konig, S.; Hinard, V.; Arnaudeau, S.; Holzer, N.; Potter, G.; Bader, C.R.; Bernheim, L. Membrane Hyperpolarization Triggers Myogenin and Myocyte Enhancer Factor-2 Expression during Human Myoblast Differentiation. J. Biol. Chem. 2004, 279, 28187-28196. [CrossRef] [PubMed]

23. Konig, S.; Béguet, A.; Bader, C.R.; Bernheim, L. The calcineurin pathway links hyperpolarization (Kir2.1)-induced Ca ${ }^{2+}$ signals to human myoblast differentiation and fusion. Development 2006, 133, 3107-3114. [CrossRef]

24. Fennelly, C.; Wang, Z.; Criswell, T.; Soker, S. Sustained Depolarization of the Resting Membrane Potential Regulates Muscle Progenitor Cell Growth and Maintains Stem Cell Properties In Vitro. Stem Cell Rev. Rep. 2016, 12, 634-644. [CrossRef] [PubMed]

25. Bernheim, L.; Liu, J.H.; Hamann, M.; Haenggeli, C.A.; Fischer-Lougheed, J.; Bader, C.R. Contribution of a non-inactivating potassium current to the resting membrane potential of fusion-competent human myoblasts. J. Physiol. 1996, 493, 129-141. [CrossRef] [PubMed]

26. Bijlenga, P.; Occhiodoro, T.; Liu, J.-H.; Bader, C.R.; Bernheim, L.; Fischer-Lougheed, J. An ether-à-go-go K+ current, $\mathrm{I}_{\mathrm{h}-\mathrm{eag}}$ contributes to the hyperpolarization of human fusion-competent myoblasts. J. Physiol. 1998, 512, 317-323. [CrossRef]

27. Liu, J.-H.; Bijlenga, P.; Fischer-Lougheed, J.; Occhiodoro, T.; Kaelin, A.; Bader, C.R.; Bernheim, L. Role of an inward rectifier K current and of hyperpolarization in human myoblast fusion. J. Physiol. 1998, 510, 467-476. [CrossRef]

28. Fischer-Lougheed, J.; Liu, J.-H.; Espinos, E.; Mordasini, D.; Bader, C.R.; Belin, D.; Bernheim, L. Human Myoblast Fusion Requires Expression of Functional Inward Rectifier Kir2.1 Channels. J. Cell Biol. 2001, 153, 677-686. [CrossRef]

29. Liu, J.-H.; König, S.; Michel, M.; Arnaudeau, S.; Fischer-Lougheed, J.; Bader, C.R.; Bernheim, L. Acceleration of human myoblast fusion by depolarization: Graded $\mathrm{Ca}^{2+}$ signals involved. Development 2003, 130, 3437-3446. [CrossRef] [PubMed]

30. Hinard, V.; Belin, D.; Konig, S.; Bader, C.R.; Bernheim, L. Initiation of human myoblast differentiation via dephosphorylation of Kir2.1 $\mathrm{K}^{+}$channels at tyrosine 242. Development 2008, 135, 859-867. [CrossRef]

31. Jang, Y.-N.; Baik, E.J. JAK-STAT pathway and myogenic differentiation. JAK-STAT 2013, 2, e23282. [CrossRef]

32. Darbellay, B.; Arnaudeau, S.; König, S.; Jousset, H.; Bader, C.; Demaurex, N.; Bernheim, L. STIM1- and Orai1-dependent Store-operated Calcium Entry Regulates Human Myoblast Differentiation. J. Biol. Chem. 2009, 284, 5370-5380. [CrossRef]

33. Chen, L.; Becker, T.M.; Koch, U.; Stauber, T. The LRRC8/VRAC anion channel facilitates myogenic differentiation of murine myoblasts by promoting membrane hyperpolarization. J. Biol. Chem. 2019, 294, 14279-14288. [CrossRef] [PubMed]

34. Chen, L.; König, B.; Stauber, T. LRRC8 channel activation and reduction in cytosolic chloride concentration during early differentiation of C2C12 myoblasts. Biochem. Biophys. Res. Commun. 2020, 532, 482-488. [CrossRef] [PubMed]

35. Fioretti, B.; Pietrangelo, T.; Catacuzzeno, L.; Franciolini, F. Intermediate-conductance $\mathrm{Ca}^{2+}$-activated $\mathrm{K}^{+}$channel is expressed in C2C12 myoblasts and is downregulated during myogenesis. Am. J. Physiol. Physiol. 2005, 289, C89-C96. [CrossRef]

36. Pietrangelo, T.; Fioretti, B.; Mancinelli, R.; Catacuzzeno, L.; Franciolini, F.; Fanò, G.; Fulle, S. Extracellular guanosine-5'triphosphate modulates myogenesis via intermediate $\mathrm{Ca}^{2+}$-activated $\mathrm{K}^{+}$currents in $\mathrm{C} 2 \mathrm{C} 12$ mouse cells. J. Physiol. 2006, 572, 721-733. [CrossRef] [PubMed]

37. Tanaka, S.; Ono, Y.; Sakamoto, K. DCEBIO facilitates myogenic differentiation via intermediate conductance Ca ${ }^{2+}$ activated $\mathrm{K}^{+}$ channel activation in C2C12 myoblasts. J. Pharmacol. Sci. 2017, 133, 276-279. [CrossRef]

38. Chen, L.; König, B.; Liu, T.; Pervaiz, S.; Razzaque, Y.S.; Stauber, T. More than just a pressure relief valve: Physiological roles of volume-regulated LRRC8 anion channels. Biol. Chem. 2019, 400, 1481-1496. [CrossRef] [PubMed] 
39. Kolobkova, Y.; Pervaiz, S.; Stauber, T. The expanding toolbox to study the LRRC8-formed volume-regulated anion channel VRAC. Curr. Top. Membr. 2021, 88, 119-163. [CrossRef] [PubMed]

40. König, B.; Stauber, T. Biophysics and Structure-Function Relationships of LRRC8-Formed Volume-Regulated Anion Channels. Biophys. J. 2019, 116, 1185-1193. [CrossRef]

41. Osei-Owusu, J.; Yang, J.; Vitery, M.D.C.; Qiu, Z. Molecular Biology and Physiology of Volume-Regulated Anion Channel (VRAC). Curr. Top. Membr. 2018, 81, 177-203. [CrossRef]

42. Strange, K.; Yamada, T.; Denton, J.S. A 30-year journey from volume-regulated anion currents to molecular structure of the LRRC8 channel. J. Gen. Physiol. 2019, 151, 100-117. [CrossRef] [PubMed]

43. König, B.; Hao, Y.; Schwartz, S.; Plested, A.J.; Stauber, T. A FRET sensor of C-terminal movement reveals VRAC activation by plasma membrane DAG signaling rather than ionic strength. eLife 2019, 8, e45421. [CrossRef]

44. Pervaiz, S.; Kopp, A.; Von Kleist, L.; Stauber, T. Absolute Protein Amounts and Relative Abundance of Volume-regulated Anion Channel (VRAC) LRRC8 Subunits in Cells and Tissues Revealed by Quantitative Immunoblotting. Int. J. Mol. Sci. 2019, 20, 5879. [CrossRef] [PubMed]

45. Liu, T.; Stauber, T. The Volume-Regulated Anion Channel LRRC8/VRAC Is Dispensable for Cell Proliferation and Migration. Int. J. Mol. Sci. 2019, 20, 2663. [CrossRef] [PubMed]

46. Qiu, Z.; Dubin, A.E.; Mathur, J.; Tu, B.; Reddy, K.; Miraglia, L.J.; Reinhardt, J.; Orth, A.P.; Patapoutian, A. SWELL1, a Plasma Membrane Protein, Is an Essential Component of Volume-Regulated Anion Channel. Cell 2014, 157, 447-458. [CrossRef] [PubMed]

47. Voss, F.K.; Ullrich, F.; Münch, J.; Lazarow, K.; Lutter, D.; Mah, N.; Andrade-Navarro, M.A.; von Kries, J.P.; Stauber, T.; Jentsch, T.J. Identification of LRRC8 Heteromers as an Essential Component of the Volume-Regulated Anion Channel VRAC. Science 2014, 344, 634-638. [CrossRef]

48. Kumar, A.; Xie, L.; Stainier, D.Y.; Hinton, A.O.; Gunasekar, S.K.; Minerath, R.A.; Shen, K.; Maurer, J.M.; Grueter, C.E.; Abel, E.D.; et al. SWELL1 regulates skeletal muscle cell size, intracellular signaling, adiposity and glucose metabolism. eLife 2020, 9 . [CrossRef] [PubMed]

49. Bendahhou, S.; Donaldson, M.R.; Plaster, N.M.; Tristani-Firouzi, M.; Fu, Y.-H.; Ptácek, L.J. Defective Potassium Channel Kir2.1 Trafficking Underlies Andersen-Tawil Syndrome. J. Biol. Chem. 2003, 278, 51779-51785. [CrossRef]

50. Yoon, G.; Oberoi, S.; Tristani-Firouzi, M.; Etheridge, S.; Quitania, L.; Kramer, J.; Miller, B.; Fu, Y.; Ptáček, L. Andersen-Tawil syndrome: Prospective cohort analysis and expansion of the phenotype. Am. J. Med Genet. Part A 2006, 140A, 312-321. [CrossRef] [PubMed]

51. Plaster, N.M.; Tawil, R.; Tristani-Firouzi, M.; Canún, S.; Bendahhou, S.; Tsunoda, A.; Donaldson, M.R.; Iannaccone, S.T.; Brunt, E.; Barohn, R.; et al. Mutations in Kir2.1 cause the developmental and episodic electrical phenotypes of Andersen's syndrome. Cell 2001, 105, 511-519. [CrossRef]

52. Zaritsky, J.J.; Eckman, D.M.; Wellman, G.C.; Nelson, M.; Schwarz, T.L. Targeted Disruption of Kir2.1 and Kir2.2 Genes Reveals the Essential Role of the Inwardly Rectifying $\mathrm{K}^{+}$Current in $\mathrm{K}^{+}$-Mediated Vasodilation. Circ. Res. 2000, 87, 160-166. [CrossRef] [PubMed]

53. Dahal, G.R.; Rawson, J.; Gassaway, B.; Kwok, B.; Tong, Y.; Ptáček, L.J.; Bates, E. An inwardly rectifying $\mathrm{K}^{+}$channel is required for patterning. Development 2012, 139, 3653-3664. [CrossRef]

54. Stiber, J.; Hawkins, A.; Zhang, Z.-S.; Wang, S.; Burch, J.; Graham, V.; Ward, C.C.; Seth, M.; Finch, E.; Malouf, N.; et al. STIM1 signalling controls store-operated calcium entry required for development and contractile function in skeletal muscle. Nat. Cell Biol. 2008, 10, 688-697. [CrossRef]

55. Varga-Szabo, D.; Braun, A.; Kleinschnitz, C.; Bender, M.; Pleines, I.; Pham, M.; Renné, T.; Stoll, G.; Nieswandt, B. The calcium sensor STIM1 is an essential mediator of arterial thrombosis and ischemic brain infarction. J. Exp. Med. 2008, 205, 1583-1591. [CrossRef]

56. Li, T.; Finch, E.A.; Graham, V.; Zhang, Z.-S.; Ding, J.-D.; Burch, J.; Oh-Hora, M.; Rosenberg, P. STIM1-Ca ${ }^{2+}$ Signaling Is Required for the Hypertrophic Growth of Skeletal Muscle in Mice. Mol. Cell. Biol. 2012, 32, 3009-3017. [CrossRef] [PubMed]

57. Gwack, Y.; Srikanth, S.; Oh-Hora, M.; Hogan, P.G.; Lamperti, E.D.; Yamashita, M.; Gelinas, C.; Neems, D.S.; Sasaki, Y.; Feske, S.; et al. Hair loss and defective T- and B-cell function in mice lacking ORAI1. Mol. Cell. Biol. 2008, 28, 5209-5222. [CrossRef]

58. Vig, M.; DeHaven, W.I.; Bird, G.S.; Billingsley, J.M.; Wang, H.; Rao, P.E.; Hutchings, A.B.; Jouvin, M.-H.; Putney, J.; Kinet, J.-P. Defective mast cell effector functions in mice lacking the CRACM1 pore subunit of store-operated calcium release-activated calcium channels. Nat. Immunol. 2007, 9, 89-96. [CrossRef] [PubMed]

59. Wei-LaPierre, L.; Carrell, E.M.; Boncompagni, S.; Protasi, F.; Dirksen, R.T. Orai1-dependent calcium entry promotes skeletal muscle growth and limits fatigue. Nat. Commun. 2013, 4, 1-12. [CrossRef] [PubMed]

60. Kumar, L.; Chou, J.; Yee, C.S.; Borzutzky, A.; Vollmann, E.H.; Von Andrian, U.H.; Park, S.-Y.; Hollander, G.; Manis, J.P.; Poliani, P.L.; et al. Leucine-rich repeat containing 8A (LRRC8A) is essential for T lymphocyte development and function. J. Exp. Med. 2014, 211, 929-942. [CrossRef]

61. Przybylski, R.J.; MacBride, R.G.; Kirby, A.C. Calcium regulation of skeletal myogenesis. I. Cell content critical to myotube formation. In Vitro Cell. Dev. Biol. 1989, 25, 830-838. [CrossRef]

62. Bijlenga, P.; Liu, J.-H.; Espinos, E.; Haenggeli, C.-A.; Fischer-Lougheed, J.; Bader, C.R.; Bernheim, L. T-type alpha 1H Ca ${ }^{2+}$ channels are involved in $\mathrm{Ca}^{2+}$ signaling during terminal differentiation (fusion) of human myoblasts. Proc. Natl. Acad. Sci. USA 2000, 97, 7627-7632. [CrossRef] [PubMed] 
63. Constantin, B.; Cognard, C.; Raymond, G. Myoblast fusion requires cytosolic calcium elevation but not activation of voltagedependent calcium channels. Cell Calcium 1996, 19, 365-374. [CrossRef]

64. Przybylski, R.J.; Szigeti, V.; Davidheiser, S.; Kirby, A.C. Calcium regulation of skeletal myogenesis. II. Extracellular and cell surface effects. Cell Calcium 1994, 15, 132-142. [CrossRef]

65. Xu, Q.; Yu, L.; Liu, L.; Cheung, C.F.; Li, X.; Yee, S.-P.; Yang, X.-J.; Wu, Z. p38 Mitogen-activated Protein Kinase-, CalciumCalmodulin-dependent Protein Kinase-, and Calcineurin-mediated Signaling Pathways Transcriptionally Regulate Myogenin Expression. Mol. Biol. Cell 2002, 13, 1940-1952. [CrossRef]

66. Porter, G.; Makuck, R.F.; Rivkees, S.A. Reduction in Intracellular Calcium Levels Inhibits Myoblast Differentiation. J. Biol. Chem. 2002, 277, 28942-28947. [CrossRef]

67. Bidaud, I.; Monteil, A.; Nargeot, J.; Lory, P. Properties and role of voltage-dependent calcium channels during mouse skeletal muscle differentiation. J. Muscle Res. Cell Motil. 2006, 27, 75-81. [CrossRef]

68. Spangenburg, E.E.; Bowles, D.; Booth, F.W. Insulin-Like Growth Factor-Induced Transcriptional Activity of the Skeletal $\alpha$-Actin Gene Is Regulated by Signaling Mechanisms Linked to Voltage-Gated Calcium Channels during Myoblast Differentiation. Endocrinology 2004, 145, 2054-2063. [CrossRef]

69. Arnaudeau, S.; Holzer, N.; König, S.; Bader, C.R.; Bernheim, L. Calcium sources used by post-natal human myoblasts during initial differentiation. J. Cell. Physiol. 2006, 208, 435-445. [CrossRef]

70. Nakanishi, K.; Kakiguchi, K.; Yonemura, S.; Nakano, A.; Morishima, N. Transient $\mathrm{Ca}^{2+}$ depletion from the endoplasmic reticulum is critical for skeletal myoblast differentiation. FASEB J. 2015, 29, 2137-2149. [CrossRef]

71. Araya, R.; Riquelme, M.A.; Brandan, E.; Sáez, J.C. The formation of skeletal muscle myotubes requires functional membrane receptors activated by extracellular ATP. Brain Res. Rev. 2004, 47, 174-188. [CrossRef]

72. Seigneurin-Venin, S.; Parrish, E.; Marty, I.; Rieger, F.; Romey, G.; Villaz, M.; García, L. Involvement of the Dihydropyridine Receptor and Internal $\mathrm{Ca}^{2+}$ Stores in Myoblast Fusion. Exp. Cell Res. 1996, 223, 301-307. [CrossRef]

73. Stiber, J.A.; Tabatabaei, N.; Hawkins, A.F.; Hawke, T.; Worley, P.F.; Williams, R.S.; Rosenberg, P. Homer modulates NFATdependent signaling during muscle differentiation. Dev. Biol. 2005, 287, 213-224. [CrossRef] [PubMed]

74. Antigny, F.; Konig, S.; Bernheim, L.; Frieden, M. Inositol 1,4,5 trisphosphate receptor 1 is a key player of human myoblast differentiation. Cell Calcium 2014, 56, 513-521. [CrossRef] [PubMed]

75. Kelu, J.J.; Webb, S.E.; Parrington, J.; Galione, A.; Miller, A.L. Ca ${ }^{2+}$ release via two-pore channel type 2 (TPC2) is required for slow muscle cell myofibrillogenesis and myotomal patterning in intact zebrafish embryos. Dev. Biol. 2017, 425, 109-129. [CrossRef]

76. Kelu, J.J.; Chan, H.L.; Webb, S.E.; Cheng, A.H.; Ruas, M.; Parrington, J.; Galione, A.; Miller, A.L. Two-Pore Channel 2 activity is required for slow muscle cell-generated $\mathrm{Ca}^{2+}$ signaling during myogenesis in intact zebrafish. Int. J. Dev. Biol. 2015, 59, 313-325. [CrossRef] [PubMed]

77. Luik, R.M.; Wu, M.M.; Buchanan, J.; Lewis, R.S. The elementary unit of store-operated Ca ${ }^{2+}$ entry: Local activation of CRAC channels by STIM1 at ER-plasma membrane junctions. J. Cell Biol. 2006, 174, 815-825. [CrossRef]

78. Wu, M.M.; Buchanan, J.; Luik, R.M.; Lewis, R.S. $\mathrm{Ca}^{2+}$ store depletion causes STIM1 to accumulate in ER regions closely associated with the plasma membrane. J. Cell Biol. 2006, 174, 803-813. [CrossRef] [PubMed]

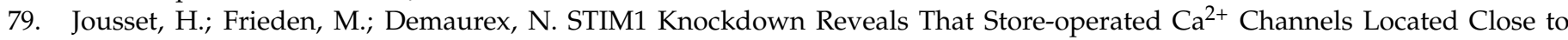
Sarco/Endoplasmic $\mathrm{Ca}^{2+}$ ATPases (SERCA) Pumps Silently Refill the Endoplasmic Reticulum. J. Biol. Chem. 2007, 282, 1145611464. [CrossRef]

80. Choi, J.H.; Jeong, S.Y.; Oh, M.R.; Allen, P.D.; Lee, E.H. TRPCs: Influential Mediators in Skeletal Muscle. Cells 2020, 9, 850. [CrossRef] [PubMed]

81. Xu, P.; Lu, J.; Li, Z.; Yu, X.; Chen, L.; Xu, T. Aggregation of STIM1 underneath the plasma membrane induces clustering of Orai1. Biochem. Biophys. Res. Commun. 2006, 350, 969-976. [CrossRef]

82. Lopez, J.J.; Salido, G.M.; Pariente, J.A.; Rosado, J. Interaction of STIM1 with Endogenously Expressed Human Canonical TRP1 upon Depletion of Intracellular $\mathrm{Ca}^{2+}$ Stores. J. Biol. Chem. 2006, 281, 28254-28264. [CrossRef]

83. Yuan, J.P.; Zeng, W.; Huang, G.N.; Worley, P.F.; Muallem, S. STIM1 heteromultimerizes TRPC channels to determine their function as store-operated channels. Nat. Cell Biol. 2007, 9, 636-645. [CrossRef]

84. Darbellay, B.; Arnaudeau, S.; Ceroni, D.; Bader, C.R.; Konig, S.; Bernheim, L. Human Muscle Economy Myoblast Differentiation and Excitation-Contraction Coupling Use the Same Molecular Partners, STIM1 and STIM2. J. Biol. Chem. 2010, 285, 22437-22447. [CrossRef] [PubMed]

85. Louis, M.; Zanou, N.; Van Schoor, M.; Gailly, P. TRPC1 regulates skeletal myoblast migration and differentiation. J. Cell Sci. 2008, 121, 3951-3959. [CrossRef] [PubMed]

86. Zanou, N.; Schakman, O.; Louis, P.; Ruegg, U.; Dietrich, A.; Birnbaumer, L.; Gailly, P. Trpc1 Ion Channel Modulates Phosphatidylinositol 3-Kinase/Akt Pathway during Myoblast Differentiation and Muscle Regeneration. J. Biol. Chem. 2012, 287, 14524-14534. [CrossRef] [PubMed]

87. Formigli, L.; Sassoli, C.; Squecco, R.; Bini, F.; Martinesi, M.; Chellini, F.; Luciani, G.; Sbrana, F.; Zecchi-Orlandini, S.; Francini, F.; et al. Regulation of transient receptor potential canonical channel 1 (TRPC1) by sphingosine 1-phosphate in C2C12 myoblasts and its relevance for a role of mechanotransduction in skeletal muscle differentiation. J. Cell Sci. 2009, 122, 1322-1333. [CrossRef] [PubMed] 
88. Meacci, E.; Bini, F.; Sassoli, C.; Martinesi, M.; Squecco, R.; Chellini, F.; Zecchi-Orlandini, S.; Francini, F.; Formigli, L. Functional interaction between TRPC1 channel and connexin-43 protein: A novel pathway underlying S1P action on skeletal myogenesis. Cell. Mol. Life Sci. 2010, 67, 4269-4285. [CrossRef]

89. Antigny, F.; Koenig, S.; Bernheim, L.; Frieden, M. During post-natal human myogenesis, normal myotube size requires TRPC1 and TRPC4 mediated $\mathrm{Ca}^{2+}$ entry. J. Cell Sci. 2013, 126, 2525-2533. [CrossRef]

90. Antigny, F.; Sabourin, J.; Saüc, S.; Bernheim, L.; Koenig, S.; Frieden, M. TRPC1 and TRPC4 channels functionally interact with STIM1L to promote myogenesis and maintain fast repetitive $\mathrm{Ca}^{2+}$ release in human myotubes. Biochim. Biophys. Acta Bioenerg. 2017, 1864, 806-813. [CrossRef] [PubMed]

91. Lee, K.H.; Park, J.-Y.; Kim, K. NMDA receptor-mediated calcium influx plays an essential role in myoblast fusion. FEBS Lett. 2004, 578, 47-52. [CrossRef] [PubMed]

92. Zanou, N.; Shapovalov, G.; Louis, M.; Tajeddine, N.; Gallo, C.; Van Schoor, M.; Anguish, I.; Cao, M.L.; Schakman, O.; Dietrich, A.; et al. Role of TRPC1 channel in skeletal muscle function. Am. J. Physiol. Physiol. 2010, 298, C149-C162. [CrossRef]

93. Timchenko, N.A.; Iakova, P.; Cai, Z.-J.; Smith, J.R.; Timchenko, L. Molecular Basis for Impaired Muscle Differentiation in Myotonic Dystrophy. Mol. Cell. Biol. 2001, 21, 6927-6938. [CrossRef] [PubMed]

94. Tajhya, R.B.; Hu, X.; Tanner, M.; Huq, R.; Kongchan, N.; Neilson, J.R.; Rodney, G.; Horrigan, F.T.; Timchenko, L.T.; Beeton, C. Functional KCa1.1 channels are crucial for regulating the proliferation, migration and differentiation of human primary skeletal myoblasts. Cell Death Dis. 2016, 7, e2426. [CrossRef] [PubMed]

95. Meola, G.; Cardani, R. Myotonic dystrophies: An update on clinical aspects, genetic, pathology, and molecular pathomechanisms. Biochim. et Biophys. Acta Mol. Basis Dis. 2015, 1852, 594-606. [CrossRef] [PubMed]

96. Li, F.; Yin, J.; Yue, T.; Liu, L.; Zhang, H. The CLIC5 (chloride intracellular channel 5) involved in C2C12 myoblasts proliferation and differentiation. Cell Biol. Int. 2010, 34, 379-384. [CrossRef] [PubMed]

97. Stauber, T.; Jentsch, T.J. Chloride in Vesicular Trafficking and Function. Annu. Rev. Physiol. 2013, 75, 453-477. [CrossRef] [PubMed]

98. Iannotti, F.A.; Panza, E.; Barrese, V.; Viggiano, D.; Soldovieri, M.V.; Taglialatela, M. Expression, Localization, and Pharmacological Role of Kv7 Potassium Channels in Skeletal Muscle Proliferation, Differentiation, and Survival after Myotoxic Insults. J. Pharmacol. Exp. Ther. 2009, 332, 811-820. [CrossRef] [PubMed]

99. Iannotti, F.A.; Silvestri, C.; Mazzarella, E.; Martella, A.; Calvigioni, D.; Piscitelli, F.; Ambrosino, P.; Petrosino, S.; Czifra, G.; Biro, T.; et al. The endocannabinoid 2-AG controls skeletal muscle cell differentiation via CB1 receptor-dependent inhibition of Kv7 channels. Proc. Natl. Acad. Sci. USA 2014, 111, E2472-E2481. [CrossRef] [PubMed]

100. Iannotti, F.A.; Barrese, V.; Formisano, L.; Miceli, F.; Taglialatela, M. Specification of skeletal muscle differentiation by repressor element-1 silencing transcription factor (REST)-regulated Kv7.4 potassium channels. Mol. Biol. Cell 2013, 24, 274-284. [CrossRef]

101. Wedhas, N.; Klamut, H.J.; Dogra, C.; Srivastava, A.K.; Mohan, S.; Kumar, A. Inhibition of mechanosensitive cation channels inhibits myogenic differentiation by suppressing the expression of myogenic regulatory factors and caspase-3 activity. FASEB $J$. 2005, 19, 1986-1997. [CrossRef]

102. Formigli, L.; Meacci, E.; Sassoli, C.; Squecco, R.; Nosi, D.; Chellini, F.; Naro, F.; Francini, F.; Zecchi-Orlandini, S. Cytoskeleton/stretch-activated ion channel interaction regulates myogenic differentiation of skeletal myoblasts. J. Cell. Physiol. 2007, 211, 296-306. [CrossRef] [PubMed]

103. Woo, J.S.; Cho, C.-H.; Kim, D.H.; Lee, E.H. TRPC3 cation channel plays an important role in proliferation and differentiation of skeletal muscle myoblasts. Exp. Mol. Med. 2010, 42, 614-627. [CrossRef] [PubMed]

104. Langlois, S.; Xiang, X.; Young, K.; Cowan, B.J.; Penuela, S.; Cowan, K.N. Pannexin 1 and Pannexin 3 Channels Regulate Skeletal Muscle Myoblast Proliferation and Differentiation. J. Biol. Chem. 2014, 289, 30717-30731. [CrossRef]

105. Araya, R.; Eckardt, D.; Maxeiner, S.; Krüger, O.; Theis, M.; Willecke, K.; Sáez, J.C. Expression of connexins during differentiation and regeneration of skeletal muscle: Functional relevance of connexin43. J. Cell Sci. 2005, 118, 27-37. [CrossRef]

106. Araya, R.; Eckardt, D.; Riquelme, M.A.; Willecke, K.; Sáez, J.C. Presence and importance of connexin43 during myogenesis. Cell Commun. Adhes. 2003, 10, 451-456. [CrossRef]

107. Afzali, A.M.; Ruck, T.; Herrmann, A.M.; Iking, J.; Sommer, C.; Kleinschnitz, C.; Preuße, C.; Stenzel, W.; Budde, T.; Wiendl, H.; et al. The potassium channels TASK2 and TREK1 regulate functional differentiation of murine skeletal muscle cells. Am. J. Physiol. Physiol. 2016, 311, C583-C595. [CrossRef]

108. Krause, R.M.; Hamann, M.; Bader, C.R.; Liu, J.H.; Baroffio, A.; Bernheim, L. Activation of nicotinic acetylcholine receptors increases the rate of fusion of cultured human myoblasts. J. Physiol. 1995, 489, 779-790. [CrossRef] [PubMed]

109. Kurosaka, M.; Ogura, Y.; Funabashi, T.; Akema, T. Involvement of Transient Receptor Potential Cation Channel Vanilloid 1 (TRPV1) in Myoblast Fusion. J. Cell. Physiol. 2016, 231, 2275-2285. [CrossRef] [PubMed]

110. Obi, S.; Nakajima, T.; Hasegawa, T.; Nakamura, F.; Sakuma, M.; Toyoda, S.; Tei, C.; Inoue, T. Heat induces myogenic transcription factors of myoblast cells via transient receptor potential vanilloid 1 (Trpv1). FEBS Open Bio 2018, 9, 101-113. [CrossRef] [PubMed]

111. Mandai, S.; Furukawa, S.; Kodaka, M.; Hata, Y.; Mori, T.; Nomura, N.; Ando, F.; Mori, Y.; Takahashi, D.; Yoshizaki, Y.; et al. Loop diuretics affect skeletal myoblast differentiation and exercise-induced muscle hypertrophy. Sci. Rep. 2017, 7, 46369. [CrossRef] [PubMed]

112. Laflamme, M.A.; Murry, C.E. Heart regeneration. Nature 2011, 473, 326-335. [CrossRef] [PubMed]

113. Senyo, S.; Steinhauser, M.L.; Pizzimenti, C.L.; Yang, V.K.; Cai, L.; Wang, M.; Wu, T.-D.; Guerquin-Kern, J.-L.; Lechene, C.P.; Lee, R.T. Mammalian heart renewal by pre-existing cardiomyocytes. Nat. Cell Biol. 2013, 493, 433-436. [CrossRef] [PubMed] 
114. Ali, S.R.; Hippenmeyer, S.; Saadat, L.V.; Luo, L.; Weissman, I.L.; Ardehali, R. Existing cardiomyocytes generate cardiomyocytes at a low rate after birth in mice. Proc. Natl. Acad. Sci. USA 2014, 111, 8850-8855. [CrossRef]

115. Später, D.; Hansson, E.M.; Zangi, L.; Chien, K.R. How to make a cardiomyocyte. Development 2014, 141, 4418-4431. [CrossRef]

116. Barreto, S.; Hamel, L.; Schiatti, T.; Yang, Y.; George, V. Cardiac Progenitor Cells from Stem Cells: Learning from Genetics and Biomaterials. Cells 2019, 8, 1536. [CrossRef] [PubMed]

117. Zwi, L.; Caspi, O.; Arbel, G.; Huber, I.; Gepstein, A.; Park, I.-H.; Gepstein, L. Cardiomyocyte Differentiation of Human Induced Pluripotent Stem Cells. Circulation 2009, 120, 1513-1523. [CrossRef] [PubMed]

118. Kleger, A.; Seufferlein, T.; Malan, D.; Tischendorf, M.; Storch, A.; Wolheim, A.; Latz, S.; Protze, S.; Porzner, M.; Proepper, C.; et al. Modulation of Calcium-Activated Potassium Channels Induces Cardiogenesis of Pluripotent Stem Cells and Enrichment of Pacemaker-Like Cells. Circulation 2010, 122, 1823-1836. [CrossRef]

119. Wang, D.; Liu, C.; Liu, H.; Meng, Y.; Lin, F.; Gu, Y.; Wang, H.; Shang, M.; Tong, C.; Sachinidis, A.; et al. ERG1 Plays an Essential Role in Rat Cardiomyocyte Fate Decision by Mediating AKT Signaling. Stem Cells 2021, 39, 443-457. [CrossRef]

120. Jeziorowska, D.; Korniat, A.; Salem, J.-E.; Fish, K.; Hulot, J.-S. Generating patient-specific induced pluripotent stem cells-derived cardiomyocytes for the treatment of cardiac diseases. Expert Opin. Biol. Ther. 2015, 15, 1-11. [CrossRef]

121. Fu, J.; Yu, H.-M.; Wang, R.; Liang, J.; Yang, H.-T. Developmental regulation of intracellular calcium transients during cardiomyocyte differentiation of mouse embryonic stem cells1. Acta Pharmacol. Sin. 2006, 27, 901-910. [CrossRef]

122. Janowski, E.; Cleemann, L.; Sasse, P.; Morad, M. Diversity of $\mathrm{Ca}^{2+}$ Signaling in Developing Cardiac Cells. Ann. New York Acad. Sci. 2006, 1080, 154-164. [CrossRef] [PubMed]

123. Tyser, R.C.; Miranda, A.; Chen, C.-M.; Davidson, S.; Srinivas, S.; Riley, P.R. Calcium handling precedes cardiac differentiation to initiate the first heartbeat. eLife 2016, 5, e17113. [CrossRef] [PubMed]

124. Linask, K.K.; Han, M.-D.; Artman, M.; Ludwig, C.A. Sodium-calcium exchanger (NCX-1) and calcium modulation: NCX protein expression patterns and regulation of early heart development. Dev. Dyn. 2001, 221, 249-264. [CrossRef] [PubMed]

125. Reppel, M.; Sasse, P.; Malan, D.; Nguemo, F.; Reuter, H.; Bloch, W.; Hescheler, J.; Fleischmann, B.K. Functional expression of the $\mathrm{Na}^{+} / \mathrm{Ca}^{2+}$ exchanger in the embryonic mouse heart. J. Mol. Cell. Cardiol. 2007, 42, 121-132. [CrossRef]

126. Li, X.; Karki, P.; Lei, L.; Wang, H.; Fliegel, L. Na ${ }^{+} / \mathrm{H}^{+}$exchanger isoform 1 facilitates cardiomyocyte embryonic stem cell differentiation. Am. J. Physiol. Circ. Physiol. 2009, 296, H159-H170. [CrossRef]

127. Hoorntje, T.; Alders, M.; van Tintelen, P.; van der Lip, K.; Sreeram, N.; van der Wal, A.; Mannens, M.; Wilde, A. Homozygous premature truncation of the HERG protein: The human HERG knockout. Circulation 1999, 100, 1264-1267. [CrossRef] [PubMed]

128. Teng, G.Q.; Zhao, X.; Lees-Miller, J.P.; Quinn, F.R.; Li, P.; Rancourt, D.E.; London, B.; Cross, J.C.; Duff, H.J. Homozygous Missense N629D hERG (KCNH2) Potassium Channel Mutation Causes Developmental Defects in the Right Ventricle and Its Outflow Tract and Embryonic Lethality. Circ. Res. 2008, 103, 1483-1491. [CrossRef] [PubMed]

129. Splawski, I.; Timothy, K.W.; Sharpe, L.M.; Decher, N.; Kumar, P.; Bloise, R.; Napolitano, C.; Schwartz, P.J.; Joseph, R.; Condouris, K.; et al. CaV1.2 Calcium Channel Dysfunction Causes a Multisystem Disorder Including Arrhythmia and Autism. Cell 2004, 119, 19-31. [CrossRef]

130. Splawski, I.; Timothy, K.W.; Decher, N.; Kumar, P.; Sachse, F.; Beggs, A.; Sanguinetti, M.C.; Keating, M.T. Severe arrhythmia disorder caused by cardiac L-type calcium channel mutations. Proc. Natl. Acad. Sci. USA 2005, 102, 8089-8096. [CrossRef] [PubMed]

131. Yoshida, T.; Owens, G.K. Molecular Determinants of Vascular Smooth Muscle Cell Diversity. Circ. Res. 2005, 96, 280-291. [CrossRef]

132. Majesky, M.W. Developmental Basis of Vascular Smooth Muscle Diversity. Arter. Thromb. Vasc. Biol. 2007, 27, 1248-1258. [CrossRef]

133. Xie, C.; Ritchie, R.P.; Huang, H.; Zhang, J.; Chen, Y.E. Smooth muscle cell differentiation in vitro: Models and underlying molecular mechanisms. Arterioscler. Thromb. Vasc. Biol. 2011, 31, 1485-1494. [CrossRef] [PubMed]

134. Sinha, S.; Iyer, D.; Granata, A. Embryonic origins of human vascular smooth muscle cells: Implications for in vitro modeling and clinical application. Cell. Mol. Life Sci 2020, 71, 2271-2288. [CrossRef]

135. Owens, G.K.; Kumar, M.S.; Wamhoff, B.R. Molecular Regulation of Vascular Smooth Muscle Cell Differentiation in Development and Disease. Physiol. Rev. 2004, 84, 767-801. [CrossRef]

136. Mack, C.P. Signaling Mechanisms That Regulate Smooth Muscle Cell Differentiation. Arter. Thromb. Vasc. Biol. 2011, 31, 1495-1505. [CrossRef]

137. Zhang, M.-J.; Zhou, Y.; Chen, L.; Wang, Y.-Q.; Wang, X.; Pi, Y.; Gao, C.-Y.; Li, J.-C.; Zhang, L.-L. An overview of potential molecular mechanisms involved in VSMC phenotypic modulation. Histochem. Cell Biol. 2015, 145, 119-130. [CrossRef] [PubMed]

138. Frismantiene, A.; Filippova, M.; Erne, P.; Resink, T.J. Smooth muscle cell-driven vascular diseases and molecular mechanisms of VSMC plasticity. Cell. Signal. 2018, 52, 48-64. [CrossRef]

139. Kudryavtseva, O.; Aalkjaer, C.; Matchkov, V. Vascular smooth muscle cell phenotype is defined by Ca ${ }^{2+}$-dependent transcription factors. FEBS J. 2013, 280, 5488-5499. [CrossRef]

140. Wan, X.-J.; Zhao, H.-C.; Zhang, P.; Huo, B.; Shen, B.-R.; Yan, Z.-Q.; Qi, Y.-X.; Jiang, Z.-L. Involvement of BK channel in differentiation of vascular smooth muscle cells induced by mechanical stretch. Int. J. Biochem. Cell Biol. 2015, 59, 21-29. [CrossRef] 
141. Johnson, M.T.; Gudlur, A.; Zhang, X.; Xin, P.; Emrich, S.M.; Yoast, R.; Courjaret, R.; Nwokonko, R.M.; Li, W.; Hempel, N.; et al. L-type $\mathrm{Ca}^{2+}$ channel blockers promote vascular remodeling through activation of STIM proteins. Proc. Natl. Acad. Sci. USA 2020, 117, 17369-17380. [CrossRef] [PubMed]

142. Zhang, B.; Chen, L.; Bai, Y.; Song, J.; Cheng, J.; Ma, H.; Ma, J.; Xie, M. miR-137 and its target T-type Ca V 3.1 channel modulate dedifferentiation and proliferation of cerebrovascular smooth muscle cells in simulated microgravity rats by regulating calcineurin/NFAT pathway. Cell Prolif. 2020, 53, e12774. [CrossRef] [PubMed]

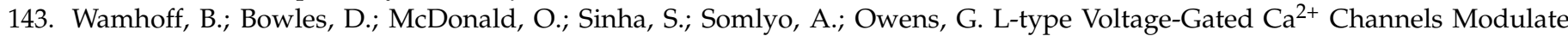
Expression of Smooth Muscle Differentiation Marker Genes via a Rho Kinase/Myocardin/SRF-Dependent Mechanism. Circ. Res. 2004, 95, 406-414. [CrossRef] [PubMed]

144. Thakore, P.; Pritchard, H.A.T.; Griffin, C.S.; Yamasaki, E.; Drumm, B.T.; Lane, C.; Sanders, K.M.; Earley, Y.F.; Earley, S. TRPML1 channels initiate $\mathrm{Ca}^{2+}$ sparks in vascular smooth muscle cells. Sci. Signal. 2020, 13, 637. [CrossRef] [PubMed]

145. Durlu-Kandilci, N.T.; Ruas, M.; Chuang, K.-T.; Brading, A.; Parrington, J.; Galione, A. TPC2 Proteins Mediate Nicotinic Acid Adenine Dinucleotide Phosphate (NAADP)- and Agonist-evoked Contractions of Smooth Muscle. J. Biol. Chem. 2010, 285, 24925-24932. [CrossRef] [PubMed]

146. Berra-Romani, R.; Mazzocco-Spezzia, A.; Pulina, M.V.; Golovina, V.A. Ca ${ }^{2+}$ handling is altered when arterial myocytes progress from a contractile to a proliferative phenotype in culture. Am. J. Physiol. Physiol. 2008, 295, C779-C790. [CrossRef] [PubMed]

147. Boie, S.; Chen, J.; Sanderson, M.J.; Sneyd, J. The relative contributions of store-operated and voltage-gated Ca ${ }^{2+}$ channels to the control of $\mathrm{Ca}^{2+}$ oscillations in airway smooth muscle. J. Physiol. 2016, 595, 3129-3141. [CrossRef]

148. Kim, B.; Molina, R.; Jensen, G.; Poburko, D. A differentiated $\mathrm{Ca}^{2+}$ signalling phenotype has minimal impact on myocardin expression in an automated differentiation assay using A7r5 cells. Cell Calcium 2021, 96, 102369. [CrossRef]

149. Teng, G.; Zhao, X.; Lees-Miller, J.P.; Belke, D.; Shi, C.; Chen, Y.; O’Brien, E.R.; Fedak, P.W.; Bracey, N.; Cross, J.C.; et al. Role of mutation and pharmacologic block of human KCNH2 in vasculogenesis and fetal mortality: Partial rescue by transforming growth factor- $\beta$. Circulation. Arrhythmia Electrophysiol. 2015, 8, 420-428. [CrossRef]

150. Numaga-Tomita, T.; Shimauchi, T.; Oda, S.; Tanaka, T.; Nishiyama, K.; Nishimura, A.; Birnbaumer, L.; Mori, Y.; Nishida, M. TRPC6 regulates phenotypic switching of vascular smooth muscle cells through plasma membrane potential-dependent coupling with PTEN. FASEB J. 2019, 33, 9785-9796. [CrossRef]

151. Bates, E. Ion Channels in Development and Cancer. Annu. Rev. Cell Dev. Biol. 2015, 31, 231-247. [CrossRef] [PubMed]

152. Sundelacruz, S.; Levin, M.; Kaplan, D.L. Role of Membrane Potential in the Regulation of Cell Proliferation and Differentiation. Stem Cell Rev. Rep. 2009, 5, 231-246. [CrossRef] [PubMed] 